\title{
Persistence at the Tree Line: Old Trees as Opportunists
}

\author{
ANDREW J. TRANT, ${ }^{1,2}$ RYAN G. JAMESON ${ }^{1}$ and LUISE HERMANUTZ
}

(Received 1 October 2010; accepted in revised form 16 February 2011)

\begin{abstract}
While old trees have long been of interest, their significant role in responding to climate change at northern tree lines has been overlooked. Long-lived black spruces at the tree line in Labrador show a radial growth response that is synchronous with recent climate warming. The ability of individuals to persist with suppressed radial growth rates during adverse growing conditions may have significant implications for the rate at which these trees are able to respond when conditions become favourable.
\end{abstract}

Key words: persistence, krummholz, dendrochronology, tree line, forest-tundra ecotone, Mealy Mountains, Labrador, climate change, black spruce, Picea mariana

RÉSUMÉ. Même si les vieux arbres revêtent de l'intérêt depuis longtemps, on a négligé de considérer le rôle important qu'ils jouent en matière de réaction au changement climatique à la hauteur des limites forestières boréales. Au Labrador, les épinettes noires de longue date se trouvant à la limite forestière affichent une croissance radiale qui est synchrone avec le récent réchauffement climatique. L'aptitude des individus à persister malgré des taux de croissance radiale opprimés lorsque les conditions de croissance sont déficitaires peut avoir des incidences importantes sur le taux de réaction de ces arbres lorsque les conditions deviennent favorables.

Mots clés : persistance, krummholz, dendrochronologie, limite forestière, écotone de toundra forestière, montagnes Mealy, Labrador, changement climatique, épinette noire, Picea mariana

Traduit pour la revue Arctic par Nicole Giguère.

Despite the recent attention given to tree-line advance resulting from climate warming (e.g., Harsch et al., 2009), the significance of old trees as the "front line" of this advance has not been adequately explored. While the persistence of long-lived trees has been reported from other climatically harsh environments (e.g., Larson et al., 2000), northern tree lines (e.g., Vallée and Payette, 2004; Asselin and Payette, 2006), and some altitudinal tree lines (LaMarche and Mooney, 1972), the importance of a persistence-mediated response to climate change deserves more attention. Long-lived clonal patches at the tree line have been used to reconstruct post-glacial migration patterns (e.g., Kullman, 2006), but the importance of ramets has been little discussed. In North America, the widely distributed black spruce (Picea mariana) is the dominant species forming these clonal patches (Pereg and Payette, 1998), making these trees ideal for exploring ideas of persistence.

On 19 July 2007, a cone-bearing, shrub-like krummholz black spruce in the Mealy Mountains, Labrador $\left(53^{\circ} 36^{\prime} \mathrm{N}\right.$, $58^{\circ} 51^{\prime} \mathrm{W}$; Fig. 1A) was sampled at ground level, using an increment borer. The sampling of this black spruce, found at $748 \mathrm{~m}$ elevation ( $\sim 130 \mathrm{~m}$ above the forest limit; sensu Scott, 1995), was part of a larger survey effort exploring patterns of age structure and reproductive potential at the alpine tree-line ecotone (for details see ppsarctic.nina.no).
Using a Velmex ${ }^{\circledR}$ micrometer (precision $0.005 \mathrm{~mm}$ ) under a binocular microscope at $40 \times$ to count annual rings, we determined that the individual's oldest living stem was at least 370 years old. A literature review and the CanDendro database (www.mta.ca/candendro) indicate that this tree is the oldest known living black spruce in Atlantic Canada and at alpine tree line across Canada. The black spruce krummholz measured $4.8 \mathrm{~m}$ by $3.1 \mathrm{~m}$, with an average stem height of $0.7 \mathrm{~m}$. The tallest of the 14 clonal stems was $1.85 \mathrm{~m}$ high, with a diameter of less than $3 \mathrm{~cm}$ at breast height and no evidence of older dead stems. Three stems produced mature pollen and seed cones in the 2007 and 2008 growing seasons, and although viability was not tested for this individual, viable black spruce pollen and seeds were documented within $585 \mathrm{~m}$ from its site (R.G. Jameson, unpubl. data).

The mechanisms by which tree lines are able to respond to climate warming may depend on how long individual trees can persist, often in suboptimal conditions, once established. Climatic conditions directly affect all stages of sexual reproduction in boreal tree species (Zasada et al., 1992; Farmer, 1996) and can limit viable seed production and the successful recruitment of new individuals, particularly toward the edge of a species' range (e.g., Elliott, 1979; Henttonen et al., 1986; Sirois, 2000). Vegetative

\footnotetext{
${ }^{1}$ Department of Biology, Memorial University, St. John's, Newfoundland and Labrador A1B 3X9, Canada

${ }^{2}$ Corresponding author: atrant@mun.ca

(C) The Arctic Institute of North America
} 


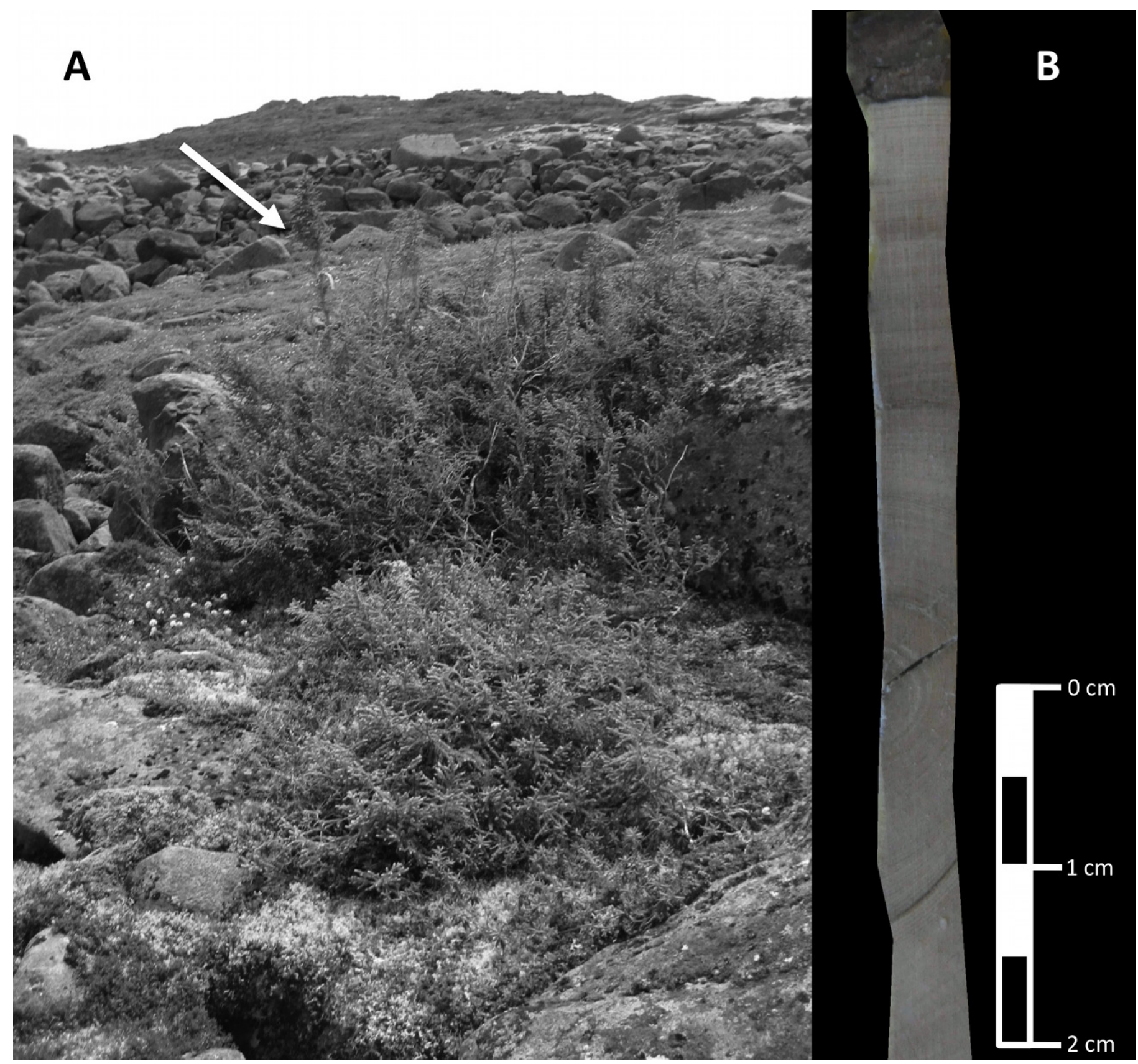

FIG. 1. Black spruce krummholz at $748 \mathrm{~m}$ elevation, near the species limit in the proposed Mealy Mountains National Park, Labrador, with A) arrow indicating tallest leader of krummholz and B) basal increment core used for age determination.

growth requires fewer growing degree-days than reproductive growth, which suggests that reproductive growth does not occur when radial growth is suppressed (Woodward, 1987). In the long term, the ability of black spruce to grow and regenerate vegetatively allows long-lived individuals to endure unfavourable climates and resume sexual reproduction when conditions improve.

Krummholz is the dominant tree form at many tree lines. These low-lying trees, the result of winter wind desiccation and ice-crystal abrasion, rarely grow higher than the average snow depth (Scott, 1995). Nurse effects of deciduous shrubs, microtopography, and glacial erratics may play a significant role in the establishment and persistence of krummholz in otherwise inhospitable environments by protecting them from increased snow drifting and sheltering them in snow-free periods (see Fig. 1; Cranston, 2009; Daley, 2009). Since growing conditions at these higher elevations are often suboptimal, krummholz put down much less radial annual wood than forest trees of the same species; in our study area, mean ring size for krummholz is $0.17 \mathrm{~mm}$, compared to $0.45 \mathrm{~mm}$ for forest trees.

Despite its old age and harsh growing conditions, the basal sample shows that the black spruce reported here has experienced a dramatic increase in annual radial growth (Fig. 2A) that matches the pattern of temperature increase observed in recent climate records (Bell et al., 2008). For 

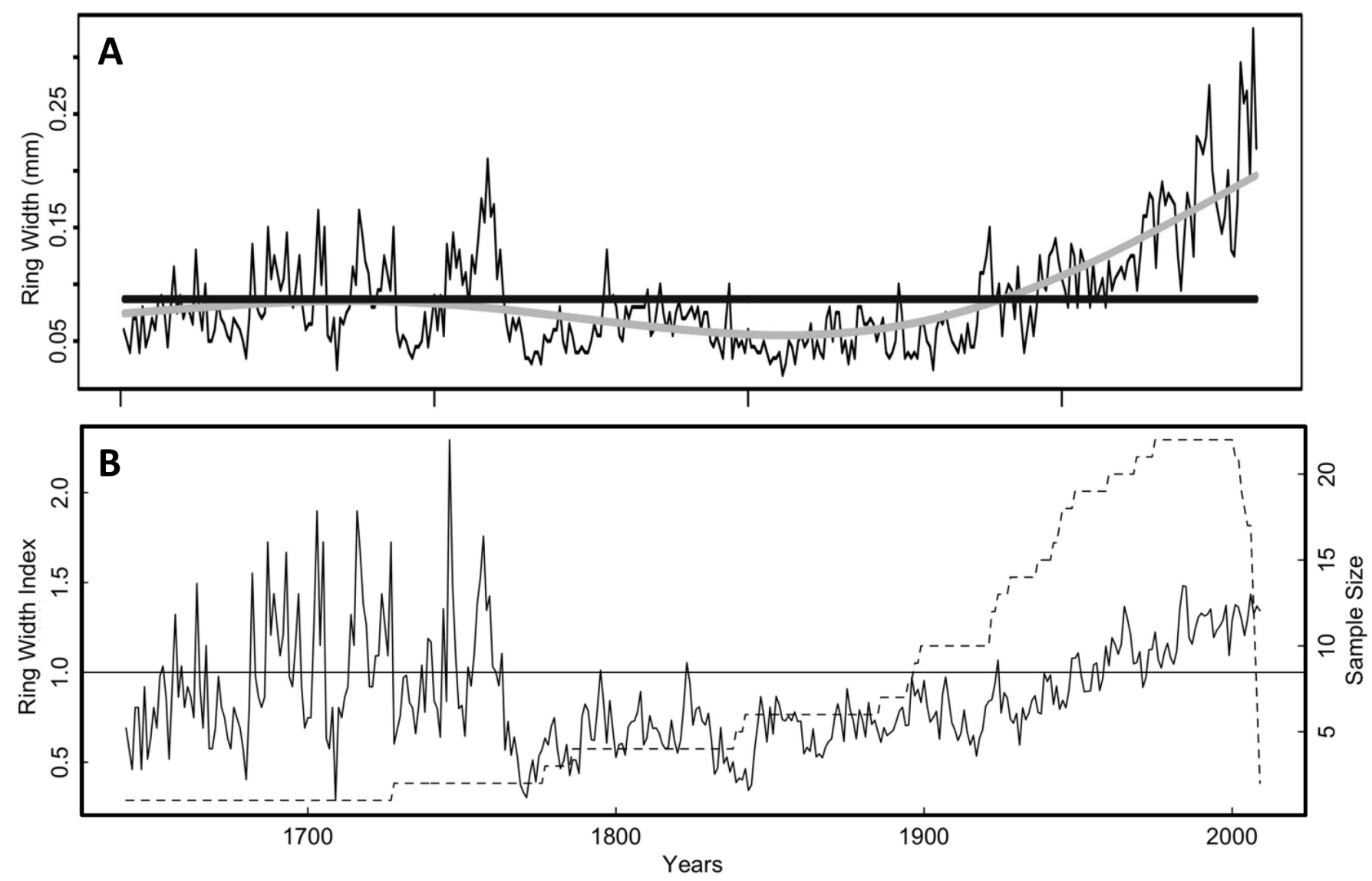

FIG. 2. Ring widths of black spruce krummholz. A) Raw ring widths for the old black spruce krummholz individual. The black line represents the overall mean, and the grey line is the running mean, with a 50-year window. B) Standardized Ring Width Index chronology of black spruce krummholz for the Mealy Mountains, Labrador. The straight black line shows the average Ring Width Index of 1, and the broken line represents sample size.

the greater part of the 20th century, ring width values were larger than the series mean, and these values have continued to increase from Little Ice Age minima around 1770 and 1850 (Fig. 2) to the present day. For the running mean (Fig. 2A: grey line), we used a 50-year window between points, excluding some of the interannual variation, in order to show this long-term trend. On a larger scale, a chronology for 22 radii from 20 stems of black spruce krummholz in the Mealy Mountains shows a similar pattern (Fig. 2B), with significant suppression of radial growth for the majority of the available record and dramatic recent increases that correspond to increases in growing-season temperature (Bell et al., 2008). This chronology was detrended using a modified negative exponential model that removes biological growth trends thus presenting standardized ring width indices.

These old krummholz may persist for centuries until conditions become more favourable, at which time they may increase radial growth rates and initiate sexual reproduction. Older trees are likely to have greater belowground biomass and access to resources essential to these processes. Once viable seeds are produced, expansion of the tree line could occur rapidly as strong winds disperse seeds from the "front line" of old tree islands. Light black spruce seeds, disseminated from semi-serotinous cones throughout the year, have the potential to travel great distances atop hard snow and ice layers during the winter. In slow-growing environments such as the tree line, the advantage may be given to those individuals who have been waiting.

\section{ACKNOWLEDGEMENTS}

We acknowledge funding from the Government of Canada Program for International Polar Year (IPY) for our work under Project PPS Arctic Canada as part of IPY 2007-08. We thank the Labrador Highlands Research Group and Megan McAndrew for assistance in the lab and in the field. Generous funding for this study was provided by the Northern Scientific Training Program, the Arctic Institute of North America, and Memorial University. We extend our sincere gratitude to the Innu Nation, who allow us to work on their traditional land. We also appreciate the helpful suggestions from John Jacobs, Janet Jorgenson, and an anonymous reviewer.

\section{REFERENCES}

Asselin, H., and Payette, S. 2006. Origin and long-term dynamics of a subarctic tree line. Ecoscience 13:135-142. 
Bell, T., Jacobs, J.D., Munier, A., LeBlanc, P., and Trant, A.J. 2008. Climate change and renewable resources in Labrador: Looking toward 2050. Proceedings and report of a conference held in North West River, Labrador, 11-13 March. St. John's: Labrador Highlands Research Group, Memorial University of Newfoundland. 95 p.

Cranston, B. 2009. The stress gradient hypothesis: Mechanisms of plant facilitation at the forest-tundra transition (Mealy Mountains, Labrador, Canada). MSc thesis, Memorial University, St John's, Newfoundland and Labrador.

Daley, S. 2009. How rocks affect the growth of krummholz in the Mealy Mountains of Labrador. Honours thesis, Dalhousie University, Halifax, Nova Scotia.

Elliott, D.L. 1979. The current regenerative capacity of the northern Canadian trees, Keewatin, N.W.T., Canada: Some preliminary observations. Arctic and Alpine Research 11:243-251.

Farmer, R.E., Jr. 1996. Seed ecophysiology of temperate and boreal zone forest trees. Delray Beach, Florida: St. Lucie Press.

Harsch, M.A., Hulme, P.E., McGlone, M.S., and Duncan, R.P. 2009. Are treelines advancing? A global meta-analysis of treeline response to climate warming. Ecology Letters 12:1040-1049, doi:10.1111/j.1461-0248.2009.01355.x.

Henttonen, H., Kanninen, M., Nygren, M., and Ojansuu, R. 1986. The maturation of Pinus sylvestris seeds in relation to temperature climate in northern Finland. Scandinavian Journal of Forest Research 1:243-249.
Kullman, L. 2006. Old and new trees on Mt Fulufjället in Dalarna, central Sweden. Svensk Botanisk Tidskrift 99:315-329.

LaMarche, V.C., Jr. 1969. Environment in relation to age of bristlecone pines. Ecology 50:53 - 59, doi:10.2307/1934662.

Larson, D.W., Matthes, U., and Kelly, P.E. 2000. Cliff ecology: Pattern and process in cliff ecosystems. Cambridge: Cambridge University Press. 340 p.

Pereg, D., and Payette, S. 1998. Development of black spruce growth forms at treeline. Plant Ecology 138:137-147.

Scott, G.A.J. 1995. Canada's vegetation: A world perspective. Montreal and Kingston: McGill-Queen's University Press. $404 \mathrm{p}$.

Sirois, L. 2000. Spatiotemporal variation in black spruce cone and seed crops along a boreal forest-tree line transect. Canadian Journal of Forest Research 30:900-909.

Vallée, S., and Payette, S. 2004. Contrasted growth of black spruce (Picea mariana) forest trees at treeline associated with climate change over the last 400 years. Arctic, Antarctic, and Alpine Research 36:400-406.

Woodward, F.I. 1987. Climate \& plant distribution. Cambridge: Cambridge University Press.

Zasada, J.C., Sharik, T.L., and Nygren, M. 1992. The reproductive process in boreal forest trees. In: Shugart, H.H., Leemans, R., and Bonan, G.B., eds. A systems analysis of the global boreal forest. Cambridge: Cambridge University Press. 85-125. 